\title{
Climate change and emerging agriculture complexities
}

\section{Mini review}

At the outset, there seems to be a nagging question that "how come Climate Change has become the only burning problem in the agricultural sector, of late? What about farm penury? What about farmers' suicides? What about food security? What about health impacts of pesticide use? What about alarming rate of groundwater depletion?' Certainly all these issues are already part of the agricultural situation and the 'inconvenient truth' is that climate change is only likely to aggravate some or many, if not all. And since climatic factors serve as direct inputs to agriculture, any change in climatic factors is bound to have a significant impact on crop yields and production. ${ }^{1-9}$ In addition, in a scenario of diversion of food crops towards commercial or high value crops, the implications of climate change often crisscrosses the boundaries between food security and poverty. It has become more pertinent that farmers in general, now, had to adjust to the implications of climatic variability while also simultaneously battle out the economic stress which itself being the product of everspiraling farm crisis.

But, in fact, climate change per se is not necessarily harmful; the problems arise from its extreme events that are difficult to predict. ${ }^{10}$ Climate change implications have already set in asmeasured by increasing temperatures, variable and unreliable rainfall and an increase in climate-relatedextreme events such as floods, droughts, cyclone, sea level rise, salinity and soil erosion. ${ }^{11}$ Changes in seasons and seasonal length are an indicator, as well as an effect, of climate change. Seasonal change profoundly affects the balance of life in ecosystems and impacts essential human activities including agriculture and irrigation. The world nations have good reasons to be concerned about climate change as it could adversely affect the achievement of vital development goals related to socio economic development, human welfare, health, energy availability and use, and infrastructure.

Besides, food security is directly related to climate change because any variability in climatic factor can directly affect a country's ability to feed its people. ${ }^{12}$ It affects all the components (i.e. production, distribution, processing, marketing, and consumption) of food security. ${ }^{13}$ Availability of food gets affected by climate change directly through its impact on crop yields, crop pests and diseases and soil fertility. ${ }^{14}$ Thereby, stability of food, crop yields, and food supplied are negatively affected due to any variation in climatic variables. The economic capacity of population to access the food may also get affected due to any increment in food prices. Overall, the impact of climate change may result in the reduction of agricultural production and employment opportunities of population and it would pose serious threat for hunger, food insecurity, poverty and malnutrition. It is now widely recognized that developing countries are particularly vulnerable to the impact of climate variability and change especially when compared to developed countries. ${ }^{7}$ This is because in developing countries ecological environments are fragile and the susceptibility of economic systems to risks is high. Besides, there is low level of technological progress, lack of resources to mitigate the adverse effect

\author{
Volume 6 Issue 3 - 2017
}

\author{
Swaminathan B,' Muraligopal $\mathrm{S}^{2}$ \\ 'Assistant Professor, Department of Agricultural Economics, \\ Junagadh Agricultural University, India \\ ${ }^{2}$ Professor, Department of Agricultural Economics, Tamil Nadu \\ Agricultural University, India
}

Correspondence: Swaminathan B, Assistant Professor, Department of Agricultural Economics, Junagadh Agricultural University, India, Email beswami@gmail.com

Received: July 25, 2016 | Published: February 06, 2017

of climate change; and due to their greater dependence on agriculture for livelihood of large populations. ${ }^{15}$

A country's vulnerability to climate change is decided by the presence of appropriate mitigation and adaptation interventions. Various studies ${ }^{16-19}$ provide abundant evidence that such interventions have a direct and indirect positive impact on farm efficiency. In addition, as interventions disseminate information on crop and livestock practices; optimal input use; and consultation directly with farmers on specific production problems, they result in facilitating a shift to more efficient methods of production. This way, these agricultural interventions not only accelerate the diffusion process of the adoption of new varieties and technologies but also improve the managerial ability of farmers, besides contributing to the efficient utilization of existing technologies by improving farmers' technical know-how. It is certainly becoming true that the presence of uncertainty in the farming sector has certainly lead farmers to value interventions that are comprehensive, real-time and idiosyncratic contrary to the more generic or piecemeal information usually provided, in general, by public and private extension agencies. ${ }^{20}$

In this connection, the role of development leading to the building of capacities, institutions and human capital, emerges ipso facto as the key for enhancing adaptive capacities. As a virtuous circle, enhanced adaptive capacities can itself stimulate further development. For instance, for the vast rain-dependent small, marginal and mediumlevel farmers in many developing countries, an insurance cover against crop failures due to a bad monsoon as an adaptation measure to climate change impacts could provide more stable economic conditions to plan at least 2-3years ahead, otherwise farmers can only plan ahead from crop-to-crop with no chance for any planning for the future. ${ }^{21,22}$ Such rural stability is needed for sustained implementation of rural development policies such as land reforms, institutionalization of sources of credits, providing direct market access for farming inputs and selling produce, extending electricity access and affordability, and extending quality education and healthcare. Thereby, interventions are 
strongly needed for developing the technical, policy and investment conditions in a region for achieving sustainable agricultural development and food security under the current precipitous scenario climate variability-farm vulnerability nexus.

\section{Acknowledgements}

None.

\section{Conflict of interest}

The author declares no conflict of interest.

\section{References}

1. Ahmad J, Dastgir A, Haseen S. Impact of climate change on agriculture and food security in India. International Journal of Agricultural Environmental and Biotechnology. 2011;4(2):129-137.

2. Anderson JR, Feder G. Agricultural extension: good intentions and hard realities. The World Bank Research Observer. 2003;19:41-60.

3. Cline WR. Global warming and agriculture: Impact estimates by country. NW, Washington DC USA: Peterson Institute of International Economics; 2007.

4. Dinar A, Keynan G. Economics of paid extension: lessons from experience in Nicaragua. American Journal of Agricultural Economics. 2001;88(2):769-776.

5. Dinar A. Extension commercialization:how much to charge for extension services. American Journal of Agricultural Economics. 1996;78(1):112 .

6. Evenson Robert. The economic returns of agricultural extension to agricultural and rural development. In Swanson B, et al. editors. Improving Agricultural Extension: A Reference Manual. Rome, Italy: Food and Agricultural Organization'; 1997.

7. FAO. Climate change and food security: A framework document. Rome: Food and Agriculture Organization; 2008.

8. Garg A, Shukla PR, Vidyasagar RM, et al. Farmers'Suicides in Andhra Pradesh and Karnataka. Centre for Social Development, Hyderabad: National Institute of Rural Development; 2003.

9. Greg EE, Anam BE, William MF, et al. Climate change, food security and agricultural productivity in African: Issues and policy directions. International Journal of Humanities and Social Science. 2011;21(1):205-223.

10. Huffman WE, Orazem PF. Agriculture and human capital in economic growth:Farmers, schooling and nutrition. Handbook of Agricultural Economics. 2007;3:2281-2341.
11. IPCC. Climate Change 2007:the physical science basis. In: Solomon S, et al. editors. Contribution of Working Group I to the Fourth Assessment Report of the Intergovernmental Panel on Climate Change. Cambridge, UK: Cambridge University Press; 2007. p. 1-996.

12. Kang Y, Khan S, Ma X. Climate change impacts on crop yield, crop water productivity and food security - a review. Progress in Natural Science. 2009;19(12):1665-1674.

13. Mall RK, Singh R, Gupta A Sinivasan G, et al. Impact of climate change on Indian agriculture: A review. Climatic Change. 2006;78(2):445-478.

14. Min S, Zhang X, Zwiers FW, et al. Human contribution to more intense precipitation extremes. Nature. 2011;470:378-381.

15. Nath PK, Behera B. A critical review of impact of and adaptation to climate change in developed and developing economies. Environment Development and Sustainability. 2011;13(1):141-162.

16. Rosenzweig C, Tubiello FN, Goldberg R, et al. Increased crop damage in the US from excess precipitation under climate change. Global Environmental Change: Human and Policy Dimensions. 2002;12:197202.

17. Sarker AR, Alam K, Gow J. Exploring the relationship between climate change and rice yield in Bangladesh:An analysis of time series data. Agricultural Systems. 2012;112:11-16.

18. Seo N, Mendelsohn R. A ricardian analysis of the impact of climate change on south american farms. Chilean Journal of Agricultural Research. 2008;68(1):69-79.

19. Surendran A, Ashok KR, Kulshreshtha SN, et al. Does climate variability influence crop yield ? - a case study of major crops in Tamil Nadu. Agricultural Economics Research Review. 2014;27(1):61-71.

20. Swaminathan B, Anandaraja N, Manikanda Boopathi N, et al Leapfrogging the Interventions of ICT Tools in Vegetable Intensification Pathways of Tamil Nadu: Farm Level Perceptions. Agricultural Economics Research Review. 2014;27:93-101.

21. Vijayasarathy K, Ashok KR. Economic impact of climate variability on agriculture in areas of high climate variability in Tamilnadu- Ricardian approach. Karnataka Journal of Agricultural Sciences. 2015;28(5):775779 .

22. Zhang T, Zhu J, Wassmann R. Responses of rice yields to recent climate change in China:an empirical assessment based on long-term observations at different spatial scales (1981-2005). Agricultural and Forest Meteorology. 2010;150(7-8):1128-1137. 